\title{
Availability Of Ground-Water Data For California, Water Year 2003
}

\section{INTRODUCTION}

The U.S. Geological Survey, Water Resources, in cooperation with Federal, State, and local agencies, obtains a large amount of data pertaining to the groundwater resources of California each water year (October 1-September 30). These data constitute a valuable database for developing an improved understanding of the water resources of the State. Beginning with the 1985 water year and continuing through 1993, these data were published in a report series entitled "Water Resources Data for California, Volume 5. Ground-Water Data." Prior to the introduction of this series, historical ground-water information was published in U.S. Geological Survey Water-Supply Papers.

In 1994, the Volume 5 GroundWater Data report was discontinued, but data continue to be available in our databases. This Fact Sheet serves as an index to ground-water data for water year 2003. The 2-page report contains a map of California showing the number of wells (by county) with available waterlevel and water-quality data for water year 2003 (fig. 2) and instructions for obtaining this and other ground-water information contained in the databases of the U.S. Geological Survey, Water Resources, California District.

\section{HYDROLOGIC CONDITIONS}

Because the geography and geology of California are so complex, ground-water conditions are difficult to summarize. Ground-water levels are affected by short- and long-term climatic conditions and also by ground-water withdrawals, irrigation returns, and other factors.

\section{DATA COLLECTION}

\section{WATER-LEVEL MEASUREMENTS}

Measurements of water levels are made in many types of wells under varying conditions, but they are made using standard methods and equipment to ensure that these measurements are consistently accurate and reliable. All water levels in the California database are given in feet with reference to landsurface datum.

\section{WATER-OUALITY MEASUREMENTS}

The quality of ground water ordinarily changes slowly; therefore, a single annual sampling usually is sufficient to define ground-water quality in most settings. If the quality of ground water is likely to change rapidly because of special circumstances, more frequent sampling may be done to identify the nature of the change.

\section{WELL-NUMBERING SYSTEM}

Wells and springs in California are assigned numbers according to their location in the rectangular system for the subdivision of public land. For example, in the number 005S012E22P001M (fig. 1), the first four characters indicate the township (T. 5 S.), and the next four characters indicate the range (R.12 E.); the two digits following the range indicate the section (sec. 22); and the letter following the section indicates the 40-acre subdivision of the section. Within each 40-acre subdivision, the wells are numbered serially, as indicated by the last three digits. The final letter indicates the baseline and meridian designation as follows: H, Humboldt; M, Mount Diablo; $\mathrm{S}$, San Bernardino. This 15-digit number is called the Local Number or State Well Number.

\section{DATA AVAILABILITY}

Data may be accessed directly through the USGS National Water Information Website (NWISWeb) at:

http://waterdata.usgs.gov/nwis/

For other information on how to obtain data, send email or call: tchaltom@usgs.gov (916-278-3100) for northern California data; jahuff@usgs.gov (858-637-6823) for southern California data.

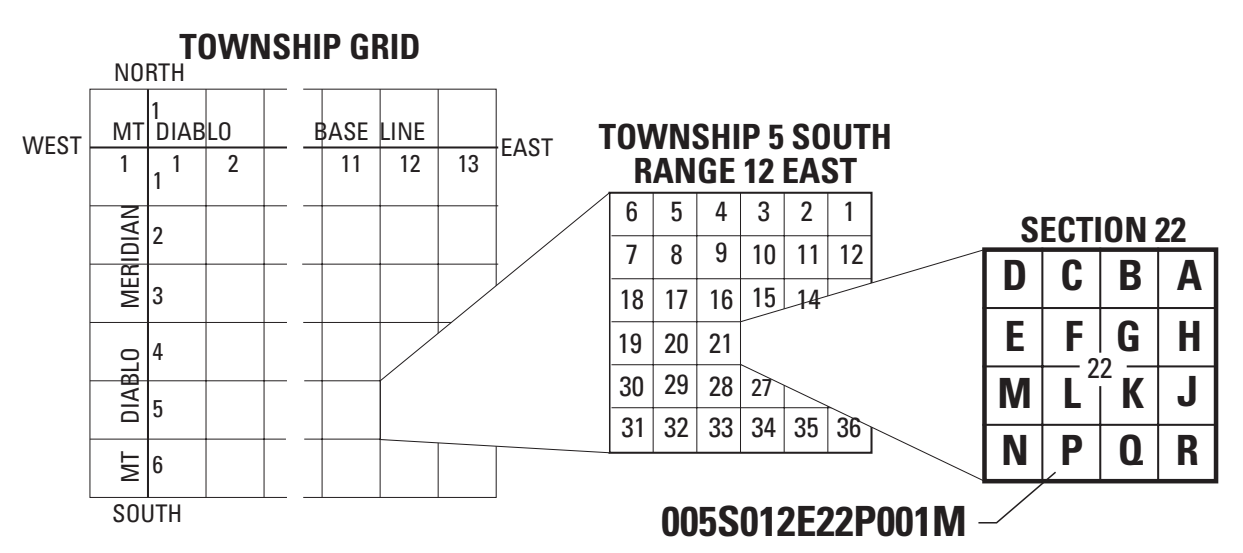

Figure 1. Well-numbering system. 


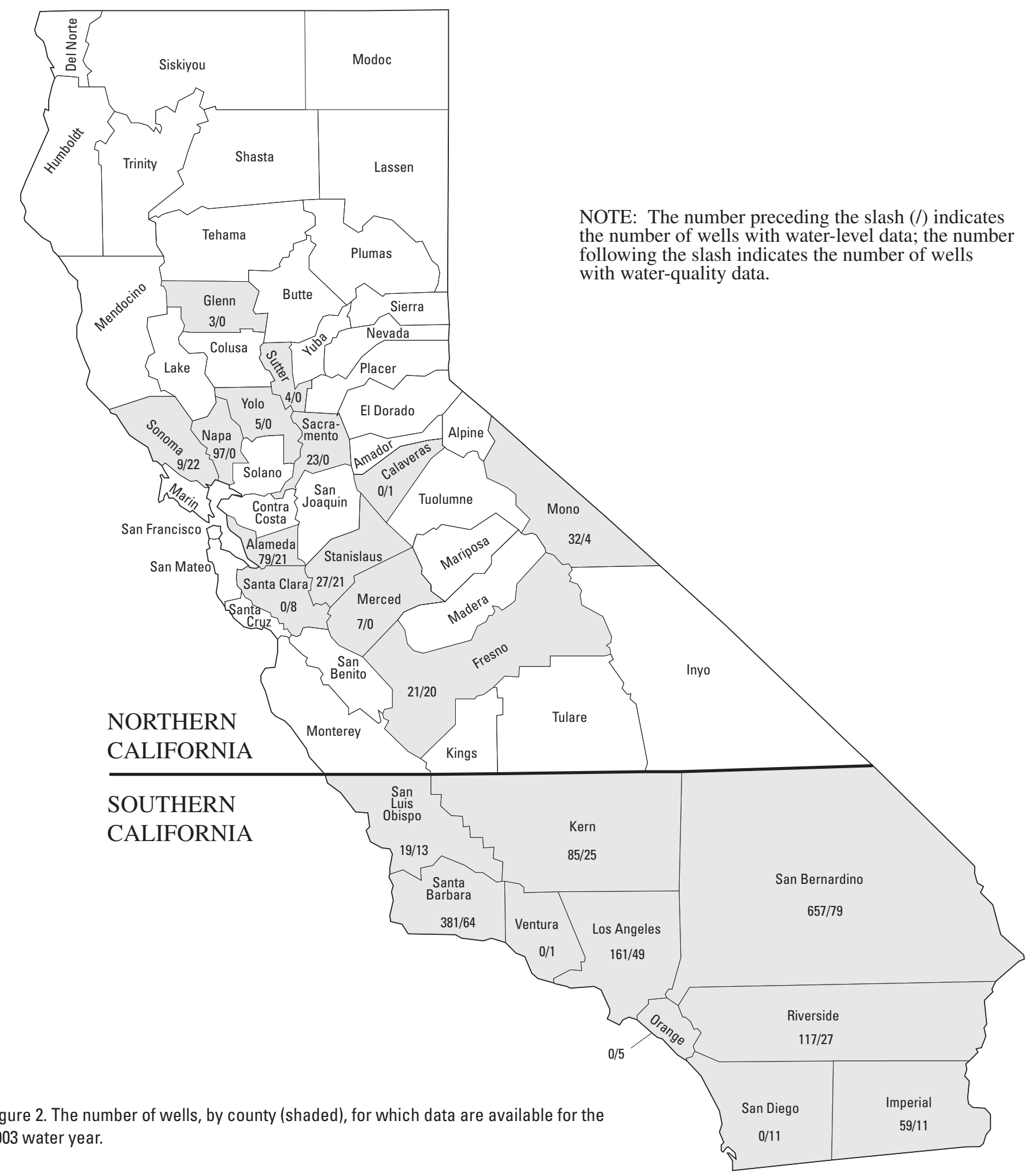

For more information on ground water in California please write to:

Julia A. Huff

Technical Information Specialist

U.S. Geological Survey, Water Resources Division

Access this fact sheet and other U.S. Geological Survey water resources information at:

5735 Kearny Villa Rd., Suite O

San Diego, CA 92123 